\title{
Pengembangan Ruang Terbuka Hijau Kawasan Sungai Winongo Di Kricak Kota Yogyakarta
}

\author{
Wahidatul Rizqi Firianti \\ Pascasarjana UIN Sunan Kalijaga Yogyakarta, Indonesia \\ Email : wahidatulrizqi16@gmail.com
}

\begin{abstract}
ABSTRAK
Kuantitas dan kualitas ruang terbuka publik terutama Ruang Terbuka Hijau (RTH) saat ini mengalami penurunan yang sangat signifikan dan mengakibatkan penurunan kualitas lingkungan hidup perkotaan yang berdampak keberbagai sendi kehidupan perkotaan antara lain sering terjadinya banjir, peningkatan pencemaran udara, dan menurunnya produktivitas masyarakat akibat terbatasnya ruang yang tersedia untuk interaksi sosial. Tujuan Penelitian ini adalah untuk menjelaskan analisis pengembangan Ruang terbuka hijau dan kritik teori didalamnya. Metode yang digunakan adalah kualitatif. Setelah data lapangan lengkap selanjutnya dianalisis dengan menarik sebuah kesimpulan. Untuk menguji hasil data lapangan, penulis mencoba melakukan validitas dengan metode trianggulasi. Hasil temuan penelitian ini adalah adanya tiga upaya pengembangan Ruang Terbuka Hijau yang partisipatif yakni, Ekologis, Edukatif, dan ekonomis guna berdaya saing dengan era globalisasi dalam pembangunan berkelanjutan. Selain itu juga ada beberapa kritikan tokoh yang melihat pengembangan kawasan ini sebagai batasan pertumbuhan dibidang biofisik dan etika sosial. Penulis juga menemukan beberapa kebijakan yang terkait dengan pengembangan Ruang Terbuka Hijau dan analisis pengembangan kawasan Ruang Terbuka Hijau.
\end{abstract}

Kata Kunci : Ruang Terbuka Hijau, Kritik Tokoh, Pengembangan Kawasan

\begin{abstract}
The quantity and quality of public open spaces Green Open Space (RTH) is currently discussing a very significant decline and rejecting the quality of the environment that increases in various joints of urban life including frequent flooding, increased air pollution, and the increase available for social interaction. The purpose of this study is to explain the analysis of the development of green open spaces and theoretical criticism in it. The method used is qualitative. After the field data is finished, it is analyzed by drawing conclusions. To answer the results of the field data, the author tries to do validity with the triangulation method. The results of this study are three results of the development of participatory Green Open Space namely, Ecological, Educative, and economic use that are competitive with the era of globalization in maintenance development. In addition there are also some criticisms of figures who see the development of this region as a substitute for growth in the field of biophysical and social ethics. The author also discovers several policies related to the development of Green Open Spaces and analysis of the development of Green Open Spaces
\end{abstract}

Keywords : Green open space, Figure Critics, Regional Development 


\section{PENDAHULUAN}

Salah satu yang menjadi kebutuhan masyarakat khususnya di wilayah perkotaan adalah ruang publik. Dimana ruang publik sebagai sarana penunjang masyarakat berhak melakukan secara merdeka didalamnya termasuk mengembangkan wacana publik seperti menyampaikan pendapat secara lisan dan tertulis. Aspek lingkungan hidup merupakan salah satu komponen yang menjadi pertimbangan dasar dalam kegiatan penataan ruang. Hal ini agar keputusan yang diambil dalam penataan ruang untuk kepentingan pembangunan dapat berkelanjutan serta tidak menimbulkan persoalan baru baik secara ekonomi, sosial budaya maupun fisik lingkungan. Berbagai perubahan kondisi lingkungan dapat berpengaruh buruk terhadap manusia. Berbagai bentuk perusakan lingkungan, seperti pencemaran udara, pencemaran air, dan menurunnya kualitas lingkungan akibat bencana alam, hal ini tentunya bisa berdampak global pada lingkungan, khususnya bagi kesehatan masyarakat sendiri. Aspek lingkungan hidup merupakan salah satu komponen yang menjadi pertimbangan dasar dalam kegiatan penataan ruang. Hal ini agar keputusan yang diambil dalam penataan ruang untuk kepentingan pembangunan dapat berkelanjutan serta tidak menimbulkan persoalan baru baik secara ekonomi, sosial budaya maupun fisik lingkungan. Sampai saat ini pemanfaatan ruang masih belum sesuai dengan harapan yakni terwujudnya ruang yang nyaman, produktif, dan berkelanjutan. Menurunnya kualitas ruang publik disebabkan ketidakseimbangan antara lahan yang ada di perkotaan dan pendatang baru yang datang ke kota serta semakin hilangnya ruang terbuka hijau di daerah perkotaan.

Adanya lahan bekas tempat pembuangan sampah akhir di RT 61 RW 01 Kelurahan Kricak, Kecamatan Tegalrejo dapat dikembangkan sebagai salah satu alternatif pengembagan ruang terbuka hijau publik. Adanya pengembangan ruang terbuka publik di lahan eks tempat pembuangan sampah tersebut diharapkan dapat menjadi contoh pengembangan kawasan lindung di sempadan sungai yang dapat diterapkan di beberapa kawasan lindung sempadan sungai yang lainnya. Dari latar belakang diatas penulis ingin mengkaji lebih dalam terkait Bagaiamana analisis Kritik teoritis dan empiris yang ada di pengembangan Ruang Terbuka Hijau pada Kawasan Sungai Winongo di Kricak Kota Yogyakarta. Dalam hal ini bertujuan untuk mendeskripsikan Kritik Teoritis dan empiris yang ada di studi kasus tersebut. 
Sampai saat ini pemanfaatan ruang masih belum sesuai dengan harapan yakni terwujudnya ruang yang nyaman, produktif, dan berkelanjutan. Menurunnya kualitas ruang publik disebabkan ketidakseimbangan antara lahan yang ada di perkotaan dan pendatang baru yang datang ke kota serta semakin hilangnya ruang terbuka hijau di daerah perkotaan.

Pertumbuhan penduduk dan aktivitas ekonomi di wilayah perkotaan dapat mempengaruhi ketersediaan lahan. Pembangunan fisik yang terjadi di wilayah perkotaan berupa pembangunan fasilitas perkotaan, perumahan, kawasan industri, perdagangan dan jasa dan sarana prasarana transportasi akan berdampak pada keberadaan ruang publik di area perkotaan. Keberadaan ruang terbuka hijau merupakan salah satu unsur penting dalam membentuk lingkungan kota yang nyaman dan sehat. Ketersediaan ruang terbuka hijau merupakan bagian dari penataan ruang kawasan perkotaan yang memiliki manfaat kehidupan yang sangat tinggi dan mempertahankan kualitas lingkungan sekitar serta tempat interaksi sosial bagi masyarakat perkotaan. Penggunaan lahan di Kecamatan Tegalrejo pada tahun 2007 didominasi oleh lahan permukiman, penggunaan lahan yang mengalami peningkatan adalah perumahan, perusahaan dan jasa. Peningkatan ini menggambarkan dinamika perekonomian Kecamatan Tegalrejo yang ditopang oleh permukiman.

Adapun pada tahun 2013 terjadi perubahan penggunaan lahan bertambah luasan yaitu lahan pemukiman bertambah di Kecamatan Tegalrejo penggunaan lahan yang mengalami perubahan yaitu pertanian semakin berkurang. Revitalisasi lahan terbuka hijau mutlak dilakukan di Kecamatan Tegalrejo sebagai imbangan atas bertambahnya lahan permukiman yang semakin bertambah. Peluang pemanfaatan lahan lindung sungai amat besar mengingat tidak adanya perubahan yang signifikan kawasan lindung sempadan sungai menjadi permukiman. Dari tahun 2013 hingga 2017 tercatat kawasan lindung sempadan sungai sebesar 11,7 ha. Adanya revitaslisasi kawasan lindung sempadan sungai sebagai kawasan ruang terbuka hijau publik di Kecamatan Tegalrejo diharapkan dapat menjadi salah satu tujaun rekreasi masyarakat sekaligus dapat berkontribusi untuk menambah capaian jumlah ruang terbuka hijau publik di kawasan Kota Yogyakarta.

Dalam penelitian ini akan mengkaji tentang Pengembangan Ruang Terbuka Hijau (RTH) kawasan Sungai Winongo di Kricak Tegalrejo Yogyakarta yang menjadi salah satu bentuk pemberdayaan 
masyarakat dalam lingkungan sosial dengan melihat konsep pengembangannya bersama masyarakat dan kebijakan yang mengatur terkait Ruang Terbuka Hijau. Apakah konsep pengambangan Ruang terbuka hijau mampu mengajak seluruh elemen wilayah?dan kebijakan apa saja yang sudah mengatur tentang pengembangan Ruang Terbuka Hijau yang dalam hal ini wilayhnya ada di perkotaan bantaran sungai? Tentu saja, pendekatan yang dilakukan melalui program pemberdayaan dengan bertumpuan pada masyarakat maka dari itu, artikel sebuah

\section{METODE PENELITIAN}

Pengumpulan data dengan pendekatan Kualitatif yang dilakukan di wilayah kota Yogyakarata pada tahun 2018. Data yang dikumpulkan adalah data primer dan data sekunder. Pendekatan penelitian ini menggunakan penelitian deskriptif kualitatif. karena perlu adanya observasi langsung dari lapangan. Penentuan informan dengan teknik ini

\section{HASIL DAN PEMBAHASAN}

\section{Kebijakan Pengembangan Ruang Terbuka Hijau}

Undang-Undang Nomor 26 Tahun 2007 tentang Penataan Ruang memberikan landasan untuk pengaturan ruang terbuka hijau dalam rangka mewujudkan ruang kajian perumusan kebijakan yang dijadikan blue print bagi pemerintah dalam pengembangan Ruang Terbuka Hijau kawasan Sungai Winongo di Kricak Yogyakarta dan menjadi pengembangan diskursus keilmuan sehingga menjadi wacana baru yang lebih dealektis dan diharapkan mendapat kritik tajam dari siapapun yang akan melakukan kajian lanjut mengenai konsep pengembangan RTH ini. Selain itu artikel ini juga mencoba untuk memperlihatkan bahwa dalam pengembangan wilayah dibutuhkan beberapa stakeholder didalamnya.

yaitu dengan cara menentukan beberapa kriteria. Selain itu dalam melakukan penelitian ini juga melakukan observasi dengan pengamatan obyektif., dan wawancara dengan informan yang terkait dengan pengembangan kawasan RTH. Kemudian, melakukan analisa untuk mengkaji dan memahami informasi dan kejadian yang terkumpul. Model analisis data yang digukan dalam penelitian ini adalah analisis interaktif.

kawasan perkotaan yang aman, nyaman, produktif, dan berkelanjutan. Dalam rangka implementasi Undang-Undang Nomor 26 Tahun 2007 tentang Penataan Ruang diperlukan adanya Pedoman Penyediaan dan Pemanfaatan Ruang Terbuka Hijau di Kawasan Perkotaan. Berdasarkan pertimbangan sebagaimana 
dimaksud tersebut, perlu ditetapkan Peraturan Menteri Pekerjaan Umum. Ruang terbuka hijau adalah area memanjang/jalur dan/atau mengelompok, yang penggunaannya lebih bersifat terbuka, tempat tumbuh tanaman, baik yang tumbuh secara alamiah maupun yang sengaja ditanam.

\section{Pedoman Penyediaan dan} Pemanfaatan Ruang Terbuka Hijau di Kawasan Perkotaan bertujuan untuk: menjaga ketersediaan lahan sebagai kawasan resapan air; menciptakan aspek planologis perkotaan melalui keseimbangan antara lingkungan alam dan lingkungan binaan yang berguna untuk kepentingan masyarakat; meningkatkan keserasian lingkungan perkotaan sebagai sarana pengaman lingkungan perkotaan yang aman, nyaman, segar, indah, dan bersih. Pasal 4(1).Peraturan Menteri memuat: ketentuan umum, yang terdiri dari tujuan, fungsi, manfaat, dan tipologi ruang terbuka hijau; ketentuan teknis yang meliputi penyediaan dan pemanfaatan ruang terbuka hijau di kawasan perkotaan; prosedur perencanaan dan peran masyarakat dalam penyediaan dan pemanfaatan ruang terbuka hijau .

RTH memiliki fungsi sebagai berikut Fungsi utama (intrinsik) yaitu fungsi ekologis: Memberi jaminan pengadaan RTH menjadi bagian dari sistem sirkulasi udara (paru-paru kota); pengatur iklim mikro agar sistem sirkulasi udara dan air secara alami dapat berlangsung lancar;sebagai peneduh, produsen oksigen; penyerap air hujan; penyedia habitat satwa; penyerap polutan media udara, air dan tanah, serta; penahan angin . Fungsi tambahan (ekstrinsik) yaitu:Fungsi sosial dan budaya menggambarkan ekspresi budaya lokal merupakan media komunikasi warga kota tempat rekreasi; wadah dan objek pendidikan, penelitian, dan pelatihan dalam mempelajari alam. Fungsi ekonomi: sumber produk yang bisa dijual, seperti tanaman bunga, buah, daun, sayur mayur bisa menjadi bagian dari usaha pertanian, perkebunan, kehutanan dan lainlain. Fungsi estetika meningkatkan kenyamanan, memperindah lingkungan kota baik dari skala mikro: halaman rumah, lingkungan permukimam, maupun makro: lansekap kota secara keseluruhan menstimulasi kreativitas dan produktivitas warga kota pembentuk faktor keindahan arsitektural menciptakan suasana serasi dan seimbang antara area terbangun dan tidak terbangun. Manfaatyang langsung (dalam pengertian cepat dan bersifat tangible), yaitu membentuk keindahan dan kenyamanan (teduh, segar, sejuk) dan mendapatkan bahan-bahan untuk dijual 
(kayu, daun, bunga, buah) Manfaat tidak langsung (berjangka panjang dan bersifat intangible), yaitu pembersih udara yang sangat efektif, pemeliharaan akan kelangsungan persediaan air tanah, pelestarian fungsi lingkungan beserta segala isi flora dan fauna yang ada (konservasi hayati atau keanekaragaman hayati).

Tipologi Ruang Terbuka Hijau (RTH) adalah sebagai berikut: Fisik RTH dapat dibedakan menjadi RTH alami berupa habitat liar alami, kawasan lindung dan taman-taman nasional serta RTH non alami atau binaan seperti taman, lapangan olahraga, pemakaman atau jalur-jaur hijau jalan. Fungsi : RTH dapat berfungsi ekologis, sosial budaya, estetika, dan ekonomi. Struktur ruang : RTH dapat mengikuti pola ekologis (mengelompok, memanjang, tersebar), maupun pola planologis yang mengikuti hirarki dan struktur ruang perkotaan. Kepemilikan : RTH dibedakan ke dalam RTH publik dan RTH privat.

Pasal 29 Undang Undang Udang Nomor 26 tahun 2007 tentang Penataan Ruang mengamanatkan setiap kota harus memiliki ruang terbuka $30 \%$ dari luas daerahnya dengan proporsi $20 \%$ untuk ruang terbuka hijau publik. ini merupakan ukuran minal untuk menjaga ekosistem
kota.Terget $30 \%$ dari total luas wilayah ini,dicapai dengan berbagai tahapan. Penyediaan ruang terbuka hijau publik juga harus disesuikan dengan rencana tata ruang wilayah atau disingkat ( RTRW).

RTRW tersebut sebagi pedoman dalam penyusunan rencana tata ruang. RTRW kota ini dimaksudkan sebagai acuan dalam penyusunan rencana tata ruang wilayah kota oleh pemerintah daerah kota dan pemangku kepentingan lainnya. Untuk mendukung terwujudnya Pasal 29 Undang Undang No 26 Tahun 2007 Tentang Penataan Ruang disetiap kota di Indonesia harus memiliki RTRW. untuk melaksanakan kebijakan Pasal 29 Undang undang No 26 tentang Penataan Ruang maka Kota Yogyakarta membuat Peraturan Daerah Kota Yogyakarta No 2 Tahun 2010 tentang Rencana Tata Ruang Wilayah Kota Yogyakarta.

Implementasi Kebijakan RTRW kota Yogyakarta tersebut terdapat dalam Pasal 77 Perda Daerah Kota Yogyakarta Nomor 2 Tahun 2010 tentang Rencaan Tata Ruang Wilayah Kota Yogyakarta Tahun 2010-2029 yaitu RTH publik direncanakan untuk mencapai minimal 20\% (dua puluh persen) dari luas wilayah administrasi Penyediaan 
dan pemanfaatan RTH diarahkan untuk mempertahankan dan mengendalikan fungsi lingkungan. Dalam mewujudkan kwalitas ruang diperlukan pengendalian penataan ruang yang mencakup seluruh aspek pengendalian penataan ruang. Pengendalian tersebut dilakukan dengan pengaturan zonasi (Zona Regulation). Peraturan zonasi merupakan ketentuan yang mengatur tentang persyaratan pemanfaatan ruang dan ketentuan pengendaliaannya dan di susun untuk blok/zona peruntukan yang pembagian zonanya ditentukan dalam rencana rinci tata ruang.

Konsep Pengembangan Kawasan Eks Tempat Pembuangan Akhir diharapkan memberikan tiga manfaat antara lain Ekologis; pengelolaan lahan diharapkan dapat berkontribusi menambang tutupan hijau dengan adanya pengembangan hutam kota/kampung. Edukatif; pengelolaan kawasan diharapkan dapat memberikan alternatif pembelajaran

\section{Pengembangan Kawasan Ruang}

\section{Terbuka Hijau}

Konsep Pengembangan Kawasan Eks Tempat Pembuangan Akhir diharapkan memberikan tiga manfaat antara lain Ekologis; pengelolaan lahan diharapkan dapat berkontribusi menambang tutupan hijau dengan adanya masyarakat di luar ruang sebagai pelengkap taman pintar dan memberikan beberapa materi pembelajaran pengelolaan lingkungan dan sumber daya air (tidak menutup kemungkinan untuk materi tematis lain). Ekonomis; pengelolaan kawasan memberikan dampak ekonomi kepada warga masyarakat sekitar yang diperoleh dari kegiatan di lokasi (parkir, kuliner, budidaya tanaman, dan fasilitator kegiatan) Selain konsep pengelolaan kawasan tersebut diatas, pengelolaan kawasan ini diharapkan menjadi simbol kemitraan semua pihak dalam Gerakan Gandeng Gendong. Filosofi gerakan ini adalah:Gandeng:semua elemen masyarakat bekerja sama dapat maju bersama Gendong: elemen masyarakat yang mampu membantu yang kurang mampu Pendekatan Gandeng Gendong 5K (Kota, Kampung, Komunitas, Kampus dan Korporasi), Pengembangan kawasan hutan kampung eks lahan TPA diharapkan dapat memberi ruang kontribusi pada elemen 5 $\mathrm{K}$

pengembangan hutam kota/kampung. Edukatif; pengelolaan kawasan diharapkan dapat memberikan alternatif pembelajaran masyarakat di luar ruang sebagai pelengkap taman pintar dan memberikan beberapa materi pembelajaran pengelolaan lingkungan dan sumber daya air (tidak menutup kemungkinan untuk materi 
tematis lain). Ekonomis; pengelolaan kawasan memberikan dampak ekonomi kepada warga masyarakat sekitar yang diperoleh dari kegiatan di lokasi (parkir, kuliner, budidaya tanaman, dan fasilitator kegiatan) Selain konsep pengelolaan kawasan tersebut diatas, pengelolaan kawasan ini diharapkan menjadi simbol kemitraan semua pihak dalam Gerakan Gandeng Gendong.

Filosofi gerakan ini adalah: Gandeng: semua elemen masyarakat bekerja sama dapat maju bersama Gendong: elemen masyarakat yang mampu membantu yang kurang mampu Pendekatan Gandeng Gendong 5K (Kota, Kampung, Komunitas, Kampus dan Korporasi), Pengembangan kawasan hutan kampung eks lahan TPA diharapkan dapat memberi ruang kontribusi pada elemen 5K. Gambar Pendekatan $5 \mathrm{~K}$ Dalam Pengelolaan Lahan eks TPA Kricak.

Masing-masing pemerintah kota mempunyai peran dalam progam pembangunan kebijakan yang berkaitan dengan tata ruang dan ruang terbuka hijau. Adapun OPD yang mempunyai progam tersebut adalah Dinas Lingkungan Hidup, dalam dinas ini progam yang berkaitan dengan ruang terbuka hijau adalah progam pengelolaan ruang terbuka hijau publik dan pertamanan perindang jalan, hal ini sesuai dengan perencanaan pengembangan kawasan di Kricak karena warga kricak menginginkan dan mengusulkan bahwa Eks TPA ini bisa menjadi hutan kota atau semacam RTH agar bisa menjadi tempat atau ruang warga dalam berkegiatan mengingat keterbatasan lahan yang ada di perkotaan lebih tepatnya pinggiran sungai. Selain itu, Dinas Lingkungan Hidup ini memmpunyai peran dalam lingkungan hidup yakni pengelolaan persampahan. Ini sesuai dengan permasalahan warga Kricak yang berada di RT 01 terkait adanya TPA Aktif yang menjadi salah satu kendala dalam pengembangan Kawasan Kricak. Namun, juga menjadi perhatian penting untuk dinas ini karena EKS TPA Kricak ini juga membutuhkan pembuangan sampah, pengelolaan sampah, pengurangan sampah serta pembersihan sampah karena sering terjadinya bencana ketika musim hujan maupun kemarau.

Dari hasil observasi dan wawancara dengan berbagai narasumber ditemukan beberapa karakter sosial yang berkaitan dengan pengembangan kawasan eks TPA Kricak. Beberapa kondisi dapat digolongkan dalam kekuatan, kelemahan, peluang dan ancaman. Beberapa kondisi yang ditemukan dalam observasi dan wawancara adalah sebagai berikut Mempunyai lahan yang Luas dalam 
penelitian ini lokasi pengembangan kawasan EKS TPA ini mempunya lahan yang luas kurang lebih 2 Ha. Lahan yang luas ini bisa dijadikan pengembangan kawasan wisata yang edukatif, rekreatif, dan ekologis. Selain itu, lahan ini diharapkan dapat menjadi salah satu wisata alam yang ada di Kota Yogyakarta. Sarana edukatif yang bisa di proyeksikan untuk lahan seluas ini adalah bisa dijadikan tempat outbond dan pembelajaran berbasis alam misalnya perkemahan sabtu minggu.

Untuk pengembangan rekreasi lahan ini mempunyai potensi sungai sebagai salah satu sarana untuk alternatif liburan karena sungai Winongo ini bisa dijadikan trek tubbing yang pasti kita tahu bahwa wahana air akan menjadi salah satu incara di daerah perkotaan dalam hal ini perlu adanya tawaran paket wisata. Untuk pengembangan ekologis harapannya lahan ini bisa menjadi salah satu bentuk upaya konservasi lahan yakni dijadikan hutan kota yang isinya adalah vegetasi khas Kota Yogyakarta. Adanya vegetasi ini diharapkan sebagai salah satu untuk melestarikan juga ditanami pohon buah untuk dikelola masyarakat. Berkaitan dengan pengembangan kawasan hutan kota/wisata membutuhkan lahan parkir dan fasilitas umum. Di area lahan seluas $2 \mathrm{Ha}$ ini pula dapat juga dijadikan lokasi parkir pengunjung dan pembangunan fasilitas umum seperti MCK, Tempat ibadah, dan wastafel. Kedua, adanya dukungan masyarakat salah satu kekuatan yang ada di lokasi pengembangan ini adalah dukungan warga terhadap rencana pengembangan kawasan wisata di EKS TPA Kricak. Dukungan yang diberikan oleh warga yakni berupa usulan-usulan tentang hal-hal apa saja yang sekiranya perlu dikembangkan. Selain itu, warga juga mendukung dan bersedia untuk memberikan tenaga, pikirannya untuk pengembangan kawasan wisata ini. Beberapa contoh peran serta warga antara laindalam pengelolaan parkir pengunjung warga bersedia menjadi tukang parkir,warga juga bersedia untuk menjadi fasilitator tubbing jika ada pengunjung yang hendak menyusuri Sungai Winongo. Selain itu, ada usaha sampah yang mana dalam hal ini pegepul sampah bersedia memberikan edukasi ke pengunjung apabila ada yang ingin belajar tentang pemilahan persampahan, adanya dukungan warga berupa cara mengelola tanah EKS TPA Kricak ini menjadi kebun yang ditanami pohon dan tanaman keras. Dukungan masyarakat ini secara tidak langsung akan berdampak nilai ekonomis jika pengembangan kawasan hutan kota/wisata terealisasi. Ketiga, Status tanah yang belum jelas merupakan kelemahan dalam pengembangan kawasan ini adalah 
adanya status tanah yang belum jelas. Ketidakjelasan status tanah adalah sejak di tutupnya area EKS TPA Kricak ini tahun 1997, terjadi pembagian kapling tanah menjadi 57 kapling dengan luasan antara 200 s.d. $300 \mathrm{~m} 2$. Informasi ini didapatkan dari adanya bukti faktur Pajak Bumi dan Bangunan. Walaupun demikian hingga saat ini tidak terjadi pembangunan dan pembayaran pajak bumi dan bangunan oleh pemegang kapling.

Oleh karena itu kelemahan status tanah yang kurang jelas ini akan lebih baik jika lahan ini dijadikan ruang publik dan adanya penetapan kawasan bahwa kawasan ini adalah kawasan hijau yang berarti tidak boleh ada pembangunan fisik yang dilakukan oleh perseorangan. Keempat, adanya permukiman selain status tanah yang merupakan wedi kengser di kawasan sempadan sungai, menimbulkan adanya perambahan permukiman. Salah satunya terjadi di bantaran Sungai Winongo di dekat laha EKS TPA Kricak ini. Adanya permukiman ini menjadi salah satu kelemahan pengembangan kawasan dikarenakan pembangunan warga di bantaran sungai ini. Permukiman yang belum teratur ini akan semakin banyak apabila tidak segera diatasi. Salah satu solusinya adalah dengan adanya penetaan peraturan ataupun adanya perencanaan master plan dan site plan untuk wilayah lahan tersebut. Jika tidak demikian untuk mengatasi permukiman tersebut maka perlu M3K (mundur, munggah, madhep kali) yang harapannya bisa mengurangi kekumuhan permukiman di bantaran Sungai Winongo. Kelima, permasalahan sampah ini sebenarnya tidak berada di lahan EKS TPA namun ada TPA aktif diselatan lahan kajian. Keberadaan TPA ini dapat dianggap sebagai TPA illegal. TPA ini berada di RT 01, Keberadaan TPA ini menimbulkan konflik sosial di masyarakat. Berdasarkan hasil wawancara, permasalahan sampah ini adanya warga Kricak yang berusaha di area TPA tersebut. Jika ingin menutup tempat sampah maka perlu relokasi tempat dan juga mencarikan pekerjaan untuk warga yang mendapatkan penghasilan dari sampah.

Kemudian Pengembangan kawasan wisata merupakan peluang yang ada dalam pengembangan lokasi ini adalah dapat dikembangan sebagai kawasan wisata baru. Pengembangan kawasan wisata berupa edukatif, rekreatif, dan ekologis. Hal ini dapat berdampak pada pendapatan ekonomi warga dan pertumbuhan ekonomi Kota Yogyakarta. Warga yang dapat dilatih untuk mengelola kawasan wisata dan rekreasi. Ketujuh akses jalan dan jaringan infrastruktur merupakan peluang 
yang berkaitan dengan fisik yakni mempunyai jaringan infrastruktur Jaringan infrastruktir yang dimaksud adalah adanya saluran irigasi di sekitar lokasi, adanya jaringan listrik yang memadai, akses jalan besar yang dapat menampung jenis kendaraan untuk pariwisata seperti bus dan mobil. Selain itu, adanya infrastruktur ini dapat menjadi peluang adanya pengembangan kawasan ini.

Sedangkan dalam hal ancaman adalah Rawan bencana, adanya kebakaran, longsor dan tanah turun. Ancaman kebakaran yang ada di lokasi ini disebabkan gas metana akibat proses pembusukan sampah di dalam tanah terkadang masih aktif. Pada musim kemarau beberapa titik kepulan asap masih terlihat sehingga membahayakan bendabenda yang berada di atasnya. Selain kebakaran ancaman bencana yang lain adalah tanah longsor. Tanah longsor hal ini dikarenankan tanah bergerak akibat kurang padatnya bekas timbunan sampah. Gerakan tanah ini menyebabkan beberapa pondasi rumah yang retak kedelapan adanya konflik sosial yang dimaksud adalah konflik/ permaslahan masyarakat yang kelak atau nanti/ sedang terjadi dilokasi tersebut. Konflik sosial ini misal seperti jika mau menutup TPA illegal yang ada di poin kelemahan maka akan muncul konflik sosial terhadap msayarakat berupa harus bagaimana membuang sampah, kemana membuang sampah, dan pekerjaan untuk para pengepul sampah.

Berdasarkan analisis diatas maka, adanya Kekuatan Lahan Luas dan SDM yang mendukung Peluang untuk dijadikan pengembangan kawasan wisata akan menghasilkan SDM yang dapat mengelola kawasan wisata berupa kawasan edukasi, rekreasi, dan ekologis. Selain itu, adanya lahan luas dan adanya peluang akses jalan dapat terjadi penataan kawasan yang menghasilkan site plan dan master plan kawasan terkait infrastruktur yang ada di kawasan tersebut. Sedangkan adanya kekuatan SDM yang mendukung dan ancaman bencana longsor serta tanah turun ini akan terbentuk SDM yang dapat mengelola dan mengurusi dalam pengurangan Resiko Bencana.

Kekurangan yang ada dalam lokasi ini adalah status tanah yang belum jelas dan peluang pengembangan kawasan wisata diharapkan tidak ada bangunan fisik, dan menjadikan lahan ini kawasan hijau sehingga masyarakat yang ingin membangun bangunan akan berfikir dua kali apabila ada peraturan yang tegas dari pemkot. Selain itu, adanya status tanah yang tidak jelas ini terhadap akses jalan dan jaringan infrstruktur memerlukan suatu penetapan kawasan dari pemerintah 
untuk menjadikan lahan ini sebagai ruang publik untuk masyarakat. Sedangkan banyaknya permukiman yang ada dibantaran sungai akan menimbulkan berbagai konflik sosial salah satunya tentang persampahan. Ada permasalahan sampah di sekitar lokasi pengembangan ini, yang satu adanya TPA aktif di RT 01 Kricak menimbulkan masalah sosial dikarenakan belum ada relokasi tempat untuk pembuangan sampah, disisi lain SIMPULAN

Kecenderungan terjadinya penurunan kualitas ruang terbuka public di kawasan permukiman, terutama ruang terbuka hijau (RTH) pada 30 tahun terakhir sangat signifikan. RTH yang ada sebagian bersar telah dikonversi menjadi infrastruktur perkotaan seperti jaringan jalan, gedung-gedung perkantoran, pusat perbelanjaan, dan kawasan permukiman baru. Dalam upaya mewujudkan ruang yang nyaman, produktif dan berkelanjutan, maka sudah saatnya kita memberikan perhatian yang cukup terhadap keberadaan ruang terbuka public, khususnya RTH. Konsep yang ditawarkan untuk pengembangan Ruang Terbuka Hijau ini ada 3 yakni Konsep penataan lahan, Konsep pengembangan kegiatan dan Konsep aksesbilitas ( ekologis, ekonomis, dan edukatif). adanya warga kricak yang mencari rejeki di lokasi TPA tersebut disarankan perlu untuk pengadaan bank sampah namun beum ada lokasi yang mau untuk dijadikan bank sampah. Di RT 61, permasalahan sampah tidak seperti di RT 01 dikarenakan, adanya salah satu pengepul sampah di lokasi tersebut yang mana usaha persampahan tersebut dapat meningkatkan nilai ekonomis bagi keluarganya

Berdasarkan implementasi kebijakan rencana pemanfaatan ruang diketahui kelemahan terletak pada status tanah yang belum jelas, permasalah persampahan dan bencana yang kemungkinan terjadi. Pembangunan dan pengembangan RTH perlu dilakukan dengan pendekatan bentuk dan struktur karena bentuk dan struktur RTH mempunyai hubungan yang menguntungkan dengan kualitas lingkungan di sekitarnya dan mempercepat serta mempermudah pelaksanaan pembangunan, pengembangan maupun pemeliharaan RTH. Perlu ditumbuhkan persepsi yang sama tentang RTH, baik dari para perancang, pengambil kebijakan dan masyarakat sehingga mereka yang mendapat manfaat dari hutan kota itu mempunyai motivasi dan inisiatif untuk mengelolan dan memeliharanya. Agar lebih memasyarakatkan fungsi dan peranan 
RTH untuk penanggulangan masalah lingkungan, perlu penyebarluasan dan publikasi tentang $\mathrm{RTH}$ baik oleh instansi pemerintah maupun swasta sehingga setiap lapisana masyarakat siap untuk melaksanakan pembangunan Pengembangan RTH.

Terdapat keterkaitan antara ekonomi dengan lingkungan dalam hal globalisasi. Salah satu penyesuaian yang dilakukan pada globalisasi ekonomi yakni mengenai pasar bebas telah berdampak buruk terhadap lingkungan khususnya dalam hal pembangunan berkelanjutan. Kecenderungan terjadinya penurunan kualitas ruang terbuka public di kawasan permukiman, terutama ruang terbuka hijau (RTH) pada 30 tahun terakhir sangat signifikan. RTH yang ada sebagian bersar telah dikonversi menjadi infrastruktur perkotaan seperti jaringan jalan, gedunggedung perkantoran, pusat perbelanjaan, dan kawasan permukiman baru. Dalam upaya mewujudkan ruang yang nyaman, produktif dan berkelanjutan, maka sudah saatnya kita memberikan perhatian yang cukup terhadap keberadaan ruang terbuka

\section{DAFTAR PUSTAKA}

A.S.Culla, Form Adjustment to Sustainable Development, dalam the case against Free Trade, Berkeley: North Atlantic Books, 1999:123. publik, khususnya RTH. Konsep yang ditawarkan untuk pengembangan Ruang Terbuka Hijau ini ada 3 yakni Konsep penataan lahan, Konsep pengembangan kegiatan dan Konsep aksesbilitas( ekologis, ekonomis, dan edukatif).

Akan lebih baik jika Setiap stakeholders harus menyadari arti pentingnya perencanaan ruang dan lahan dengan penyediaan RTH yang optimal, sehingga perkembangan ruang terbangun dapat berjalan serasi, selaras, dan seimbang Pengembangan RTH merupakan program yang dilakukan di seluruh kota di Indonesia, sehingga kajian dalam lingkup wilayah lain juga diperlukan agar komitmen pembangunan berkelanjutan dapat terwujud Upaya peningkatan kualitas RTH publik untuk mengoptimalkan fungsi ekologis harus disinergikan dengan program lain seperti pengembangan biopori, pengelolan, saluran dan sungai, pengelolaan sampah dan pengelolaan RTH privat secara baik. Fungsi sosial dan ekonomi RTH belum manjadi bagian dari kajian ini, sehingga dibutuhkan penelitian lebih lanjut pada fungsi tersebut.

Eva Siti Sundari, Studi Untuk menetukan fungsi hutan kota dalam masalah lungkungan perkotaan, Jurnal PWK Unisba. 
Herman Daly E. 1993. Form Adjustment to

Sustainable Development, dalam the case against Free Trade, Berkeley: North Atlantic Books.

Herman Daly, 1996, Beyond Growth: The Economics of Suistanable Development. Boston:Beacon Press.

King, Laura A., 2010. Psikologi Umum. Penerbit Salemba Humanika. Jakarta.

Laporan Bappeda, Pengembangan Kawasan Sungai Winongo, 2018

Nadia Astriani, Implikasi Kebijakan Ruang Terbuka Hijau dalam Penataan Ruang di Jawa Barat, Jurnal Ilmu Hukum vol 8 no 2 April-Juni 2014

Peraturan Menteri No. 5 Tahun 2008,

Peraturan Menteri Pasal 4 ayat 1 tentang tipologi ruang terbuka hijau

Purwanto, Edi, 2007, Ruang Terbuka hijau di Perumahan Graha Estetika Semarang, Jurnal Ilmiah Perancangan Kota dan Permukiman , Volume 6 No. 1. Maret 2007.
Robert S., 2012. Pengantar Psikologi. Penerbit Salemba Humanika. Jakarta.

Undang Undang No 26 Tahun 2007 tentang penataan Ruang 